\title{
Users' needs and expectations of urban recreational forests in Selangor, Malaysia
}

\begin{abstract}
Background: Forests or woodlands provide ecosystem services including provisioning services, cultural services, regulating services and supporting services. Recreational forests in Peninsular Malaysia areas are for recreation, research and development, and for economic benefit. Objectives: This paper examines users' needs and expectations of recreational forests in Selangor, Malaysia in relation to the maintenance and management aspects. Results: The results indicate that the respondents have various expectations related to their needs. The respondents will come more often if more facilities, activities and security provided. Conclusion: The recreational forest management should consider the users' needs and expectations in planning programs, managing and designing future recreational forests so that potential users will feel comfortable when visiting the area. Therefore, to have frequent visits, it is important to enhance the users' experience in the forest. Cultural aspects, gender and age of Malaysian users' are factors to be taken into account in ensuring a sustainable use of recreational forest.
\end{abstract}

Keyword: Use of recreational park; Maintenance; Gender; Age 